\title{
The Tale of Two Managers: A Value-Based Saga
}

\author{
Narayan Krishna Prabhu, Sri Sathya Sai Central Trust [SSSCT], India
}

\begin{abstract}
Human resource development managers are concerned about recruiting competent and valuebased people in organizations. Values can be seen at the individual, organizational and corporate levels and also in a national context. Culture and society play an important part in shaping values and behavior. This paper relates the cases of two managers, born in different periods of time, having particular generational values, and consequently different dominant work values and personality traits. The interviews with stakeholders and other role holders also echo the same. Amongst a cross-section of employees, it is seen that some values are commonly found, whereas other values are unevenly distributed. Personality attributes, as propounded by organizational experts - like Type A personality traits, proactive personality constructs, core self-evaluation risktaking and high-flyer dimensions - are seen in varying degrees in the employees. Again, there are issues like integrity, loyalty, and whistleblowing which are prevalent in a skewed manner. Organizational commitment is seen as responsible for bonding. Stories about the founder have kept the organizations surging forward. All these artifacts are seen suffused with values.
\end{abstract}

'Once you recognize the value of human life, you will be able to understand human values' (Baba, 2001, p.167).

Keywords: Human Resource Development; Values; Behavior; Personality Traits; Commitment; Storytelling

\section{INTRODUCTION}

\section{Human Resource Development \& Values}

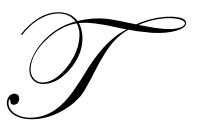

hose were the days when we had virtuous employees, top management bestowed their unconditional affection on the employees, and all organizational aspects were inclusive. There are instances, even today, of such virtuousness; it could be culture - specific! As a management function, Human Resources Development [HRD] is not only concerned about the acquisition of knowledge, skills, and abilities which is mandated by all, but it is equally concerned about generating moral, ethical, social, humanistic and spiritual values in them. HRD is not merely a tool or instrument to produce only workforce for the organization, but also to fit them in a learned and knowledgeable society. Mere professional knowledge and expertise are not enough. HRD should be actually a mission, a movement, and much more than a mere profession or a vocation. HRD should aim in creating an integrated personality and aim at the simultaneous development of the physical, mental, aesthetic, affective, artistic and intellectual, innovative, imaginative, and intuitive faculties endowed to the human beings. HRD... should synergistically blossom and sublimate ... to discover the supreme reality and achieve selfactualization. HRD should aim at a higher objective of bringing about a new species of human beings with human values for their all-round development with commitment to themselves, society, their country, and the world at large. Intellectual growth must be combined with socialization. These call for self-discovery, self-confidence, selfestimate/evaluation, self-motivation, self-learning, and self-reliance (Rao, 2004).

\section{Values: Concepts}

Values are important to the study of human beings in an organization because they lay the foundation of understanding people's attitudes, behavior, and other's perceptions. Individuals enter an organization with preconceived notions of what "ought" and "ought not" to be (Robbins et al., 2009). According to the definition by 
Schwartz $(1999,24)$, values are conceptions of the desirable that guide the way social actors (e.g. organizational leaders, policy makers, individual persons) select actions. [Schwartz has presented several definitions, all of which appear as quite similar. Other definitions in the field of social psychology can be found in Rokeach, 1973. 'Values are defined as fundamental beliefs that guide individual behavior and judgments across situations.']. A Value can be defined as a fairly permanent belief about what is appropriate, and what is not, that guides the actions and behavior of employees in fulfilling the organization's aims. Values can be thought of forming as an ideology that permeates everyday decisions (Weihrich et al., 1994, p.335). When you value something, you want it or you want it to happen. Values are relatively permanent desires that seem to be good in themselves, like peace or goodwill (Stoner et al., 2002, p.110). ... determination ... values of those affected. Values are the relatively permanent and deeply held desires of individuals (Hellriegel et al., 2001, p.421). ... the success ... attributable to its values. Values represent stable, long-lasting beliefs about what is important in a variety of situations that guide our decisions and actions (McShane et al., 2005, p.16). They are evaluative standards that help us define what is right or wrong, or good or bad, in the world (Sagie \& Elizur, 1996, p. 503 - 545).

\section{Organizational Values}

Organizationally, values are indicative of the most defining characteristics of the organization (Williams, 1979). These are the beliefs and attitude that go deep inside and constitute a collective understanding regarding the norms and standards of behavior acceptable in the organization. In that sense, values are considered as the essential component of organizational culture (Sinha, 1995, and Hatch, 1993). According to Schien (1985), corporate values are collective beliefs about what the entire enterprise stands for, takes pride in, and holds of intrinsic worth. Organization values serve many purposes. They set the tone of the environment, bond people together, and facilitate work behavior and achievement of shared goals. They also represent the ambitions that people hold for the organization as a living system because values define who and what each person has to offer as a human being to the overall enterprise (Mirabile, 1996). There must be alignment of individual and organizational values (Finegan, 2000; Neal, 1999).

\section{Corporate Values}

Sound corporate governance is essential where the organization emerges as a responsible corporate citizen (Fry, 2005). Again, in many successful companies, value-driven corporate leaders serve as role models, set the standards of performance, motivate employees, make the company special, and are a symbol to the external environment (Academy of Management Review, 1988, pp. 534 - 545). The following from James Autry (1991), exCEO of Meredith Corporation's magazine group, is an example of a corporate values statement that sends that message: We will be fair, sensitive, honest, trusting, and trustworthy in all our dealings among ourselves, with customers, with vendors, and with the community at large. We will obey all laws, in fact and in spirit, and we shall always do the right thing, in every situation to the best of our abilities. And if we fail, we will do whatever is required to make amends. Two more messages by the respective heads are penned for the value content. The principles issued by Nestlé Limited in 1977 and further revised in 2002 [from P. Brabeck-Letmathe, Chief Executive Officer] are: Members of the Nestle Management, at all levels, are strongly committed to the company, and its development and culture are expressed in The Nestle Management and Leadership principles. They practice what they preach and show the example in their daily work. Apart from professional skills and insight, the capacity and willingness to apply these principles are the main criteria for progressing in the organization, regardless of origin, religion, race, gender or age [Message issued in April 2003, Nestlé Limited, Human Resource Department, Corporate Identity and Design, Vevey, Switzerland] . As a part of Unilever Sustainable Development Overview 2009, Mr. Paul Polman, Chief Executive Officer, writes 'This way of working described as shared value creation has been at the heart of Unilever's approach since inception of the business. Today we are applying it to the challenges of the $21^{\text {st }}$ Century: climate change, water scarcity, poverty alleviation ... central issue ... how to grow in a sustainable manner'. Corporate values are paraded and dished out on the websites and annual (financial) reports of those corporations. Although it began with US corporations, it spread to Europe and now it is a world-wide phenomenon. Corporations seem to project those values for public consumption and, although in a phenomenological sense are aware that explicit values are different from the implicit values, it is the latter that actually guides our actions. If this was a truism, then Enron's values (1998) of respect, integrity, communication, and excellence should have prevented their catastrophic misbehavior. This is verily applicable to other corporations 
as well. Businesses are complex, as well as intriguing, as far as values are concerned, especially when we search for those human values consisting of principles that guide human actions (Allport, 1961). We are on the lookout for those values that motivate people to achieve and understand common goals and the way execution has to take place to achieve those common goals. This can increase organizational commitment and efficiency, but the pointer would be who determines those organizational values and whether there is a common perception in understanding them.

\section{Values in India}

Values and behavior are influenced by culture and society. Indians (and also persons of different Asian nations) often experience a clash from their home-driven inculcation of Indian culture with those acquired from 'liberal' western education and 'professional' training (Garg and Parikh, 1988; Parikh and Garg, 1990; and Tripathi, 1990). Indian values might lead to a preference for ethical awareness and ethical convention, creating a clash with the corporate preference for ethical puzzle and neutrality, leading to a struggle to balance conflicting values. Indian managers may deal with the clash of cultures by expressing Indian-based values.

Values drawn from training have influences of the west and emphasize strict compliance to what is expected, whereas values drawn from family and the community emphasize affiliation and social obligation. Dependence on the family network and heuristic and intuitive approach to decision-making were necessary strategic responses to the uncertainty that the Indian corporate sector faced in the Asian arena (Haley \& Haley, 1998). Indian managers may deal with the class of cultures by expressing Indian-based values rather than applying those perceived by Western managers in their role positions.

It is found that Indian managers, in comparison to UK managers, experience tension between their private ethical beliefs and those that they are required to apply at work. They regard family and social connections as an important aspect of conventional ethical thinking. Managers need to recognize and respond to the ethical wrongs in business and society. If good corporate citizenship is to be achieved, managers need to question their pragmatic responses and review business practices from a wider and more critical perspective. Indian managers experience a conflict between their espoused values and their values in practice, which suggests that there is a leverage point that management educators could use in their task. The quality of corporate citizenship could be improved by encouraging Indian managers to draw up their espoused values in the conduct of their jobs (Sanghi, 2002).

\section{RESEARCH METHODOLOGY}

In studying the "Value-based Saga", interviews were conducted with the two managers [in the first case when the manager was alive], their family members, employees, and other stakeholders of the organizations (including CEOs) where they worked, observing employees at work, reading documents and listening to stories about the founders and other significant role holders/visionaries of those organizations.

This paper relates to two cases - one drawn from a Multi-National Corporation located in Mumbai, India, and the other from a leading mining group in Goa, India, and the learning and research outcomes from both. In the first case, the wife of an accountant contracts cancer and she survives. In the latter, a geologist contracts cancer and he dies. It is worthwhile to journey through the sequence of events, like a river meandering through the mountains and plains before emptying itself in the ocean, experiencing the triumphs as well as the tribulations of personal and organizational life, especially when one becomes aware of the onslaught of cancer and becomes a caricature in the hands of medical fraternity. The empathetic response of the top management in both the cases is revealing: 'The management herby commits to bear all the medical expenses, all inclusive, including the expenses of the family members on account of hardship.'

\section{THE CASE OF RAY - FROM HOPELESSNESS TO HOPEFULNESS}

Mr. Ray, a qualified and competent accountant, moves to the Multi-National Corporation (MNC), located in Mumbai, India, in the first half of 2000. Ray joined the MNC with renewed zeal and enthusiasm since he had 15 years of accounting experience at the senior level in various organizations. He was a doer, both highly energetic and focused, and [had] climbed the corporate ladder since many organizations had those "fast track" systems; he would announce, "I have made it!" 
On that fateful day he had just returned to his apartment when he received the medical report that his wife had contracted cancer - a bolt from the blue! Mumbai was new to him, he had just moved from Kolkata, and was in the process of setting the dwelling place (sweet home), and schooling for the kids. The news was a blow to his family. His wife now had to regularly be taken for medical consultations and he had to be away from work for long periods. He was experiencing a conflict between the critical need in his personal life and the perceived need of new organizational-work life, new organization, and new challenges.

There was a clamor in his new organization as he was missing from most of the activities and meetings, and nobody really knew the real reasons until then. One day his superior summoned him and before any questions could be asked, he informed him of the harsh reality. The superior was moved by all that he heard and remembered the case of a family member who had to undergo similar dreadful experiences. After checking with the top brass and looking at the immense potential of Mr. Ray, the humane response was:

We shall provide the best of the medical aid available and we shall provide all the logistics - help for the children. We would provide all help so that you experience relief.

True to the words and spirit, the management contacted the best of the medical fraternity for providing necessary care. The children were admitted to the best of schools and the family also got a decent apartment, with all the amenities to live a meaningful life. Mr. Ray was also informed that all expenses would be met by the organization. Within one year, the dark clouds were cleared and his wife tested negative and was completely cured. The management had demonstrated the true meaning of welfare. He was truly relieved and felt great about joining that organization in a coveted position. Having entered employment in 1985 and turning 36 years old in the year 2000, he belonged to both Contemporary Work Cohorts - Boomers (Baby Boomers) $\left[{ }^{1}\right]$ and Xers (Generation Xers) $\left[{ }^{2}\right]$, therefore characterized with certain dominant work values.

Some of the statements made by the stakeholders and role holder are revealing:

CEO:

'Give him a challenge and the expectation is met.'

'He can take the people along.'

'He is innovative; he is creative.'

'He has managed resources well; in a crisis he is innovative in cost cutting.'

Others:

'We look forward to his leadership.'

'Very sensitive and sensible too!'

'Provides solutions to all pressing issues of the department.'

\section{Role Holder:}

'The job itself is so exciting; every moment is enchanting.'

'It is great [good] to be over here.'

'I always choose the members of our team; no meddling please.'

'I can't just forget that instance when I made it.'

'I can't forget my family.'

'I want to make it to the top.'

\section{THE CASE OF MR. DEY - THE TALENT AT ITS BEST}

Mr. Dey was a qualified geologist, hailed from East India, and picked up a job with an iron ore open cast mine in Goa, West India, as a junior geologist in the year 1962. Exceptionally talented, he rose to be the Chief Geologist of the same mining organization in a span of 25 years, the position he held until 1991 [he was 50 then] 
when he fell down unconscious while at work. He succumbed to illness [CANCER] and breathed his last on $1^{\text {st }}$ December 1998. The period, from 1991 to 1998, especially the latter part, was traumatic for both the employee and his family. The tentacles of death were slowly but surely nearing and entangling; he and his family knew he would die.

The management commitment was unique:

'We shall provide all out financial help; the family shall continue to receive the salary even in the unfortunate event of the demise of the bread-winner, and we shall also bear all the educational expenses for the professional education of the children and facilitate them to get into employment.'

In terms of the commitment, the Senior General Manager heading Personnel, HRD, and Administration left no stone unturned to provide every succor to the employee's family. All medical expenses were reimbursed, all transportation and travel expenses of the family were reimbursed, and legal help was provided so that his family members had 'Wills' and 'Power of Attorneys' prepared in case any unfortunate thing would happen, they would be equipped to handle it. Educational expenses of the children, plus facilitation for their employment, were also taken care of.

As the time passed and as years, months, days, hours, minutes and seconds rolled/ticked by, death inevitably did take away that life and management honored its commitment. Looking at his work life, it was seen that he spent three decades working for only one organization, which he fondly called his first home. Having entered employment in 1962 and turning 50 years of age in the year 1991, he belonged to both Contemporary Work Cohorts - Veterans (Traditionalists) $\left[{ }^{3}\right]$ and Boomers (Baby Boomers) $\left[{ }^{1}\right]$, therefore characterized with certain dominant work values.

Some of the statements made by the stakeholders and role holder are revealing:

CEO:

'He is a good teacher.' 'Anyone who needs practical knowledge and (words of) wisdom $\underline{\text { must }}$ contact Dey.'

'He is a perfectionist, very meticulous, often getting into the minutest detail.'

'For all technical presentations, including representing the institution at conferences, he is the only person.'

'Before applying any new mining practices of Australia and South America, I would rather confer with Dey.'

On his demise, 'I have lost my right hand.'

Others:

'It is a pleasure to be with him; he has no airs of superiority.'

'He guides and explains well.'

'So many professionals approach him for assistance; he is so humble and kind.'

'Although he knows so much, he never breaks any rule whilst working; he has solutions for everything.'

His Wife:

On his demise, 'He always thought and dreamt of his work; he did not take proper care of his own needs like food and rest.'

\section{Role Holder:}

'Thank God, I am able to serve the mine with my full capacity.'

'I know I have the rare skills and competence, let me serve the society.'

On becoming aware of his $\underline{d y i n g}$, 'Let me be of service to the mine until I breathe my last.' 


\section{A Re-Visit to the Values held by the Two Managers}

The two managers apparently held some values; they had some critical personality traits which possibly facilitated the grounding and rooting of the values. The socio-economic construct prevalent at the time of their joining employment also left behind the psycho-emotional scars of those times (causing certain generational values and dominant work values).

The dominant work values seen in both Ray and Dey are:

$\begin{array}{ll}- & \text { Success } \\ - & \text { Achievement } \\ \text { - } & \text { Ambition } \\ \text { - } & \text { Dislike of Authority } \\ & \text { Loyalty to Career }\end{array}$

Some of the dominant work values were seen in them individually:

RAY DEY

Work/ Life Balance

Team-Oriented

Dislike of Rules

Loyalty to Relationships
Hardworking

Conservative

Confirming

Loyalty to the Organization

Interactions/in-depth discussions were also held with connected persons, including family members, who confirmed the values with evidence.

Again, three decades ago, organizations were concerned only with the personality factors because their primary focus was to match individuals to specific jobs. This concern still exists as is evidenced by the traits and attributes seen in the two managers. However, the interest has now expanded to also include how well the individual's personality and values match the organization. Managers are less interested in looking at the individual's ability to perform a specific job; rather, they are looking at individual's flexibility to meet changing situations and overall commitment to the organization. Evidence for situational specificity of personality-job performance relations calls for better understanding of how personality is expressed as valued work behavior (Tett and Burnett, 2003). One also needs to look into certain personality attributes like Type A, proactive personality, core self-evaluation, self-monitoring, risk-taking, and high-flyers which have been found to be powerful predictors of behavior in organizations (Robbins et al., 2009).

\section{Type A Personality}

The individuals are excessively competitive and always seem to be experiencing a sense of time emergency. Such individuals are "aggressively involved in a chronic, incessant struggle to achieve more and more in less and less time and, if required to do so, against the opposing efforts of other things or other persons" (Friedman, and Roseman, 1974, pp. 84). Type A individuals can be described as (1) always moving, walking and eating rapidly; (2) feel impatient at the rate at which most events take place; (3) strive to think or do two or more things at once; (4) cannot cope with leisure time; and (5) obsessed with numbers and measuring their success in terms of how many or how much of everything they acquire. They operate under high level of stress, subject themselves to continuous time 
pressures, creating a life of deadlines and working long hours. Amongst the two managers, both Ray and Dey had Type A traits; however, Ray was more prone to it.

\section{Proactive Personality}

Bateman and Crant (1993) defined the construct proactive personality "as a dispositional construct that identifies differences among people in the extent to which they take action to influence their environment" (p.103). Again, the construct proactive personality encompasses the varied aspects of proactive behavior and initiative some persons actively take the initiative to improve their current circumstances, or create new ones, or challenge the status quo or voice displeasure when situations are not palatable (Crant, 2000, p. 46). Proactives identify those opportunities, show initiative, take action, and persevere until meaningful change occurs. They create positive change in the environment, regardless of, or even in spite of, constraints or obstacles (Seibert, Kraimer, and Crant, 2001, p. 850). Proactives have many desirable behaviors in the organization - they are seen as leaders and change agents (Bateman, and Crant, 1993, and Crant and Bateman, 2000). If organizations prefer people with entrepreneurial initiatives, proactives would meet the requirements. In the long run, these people are likely to leave the organization to start their own venture $\left(^{4}\right)$. They are also likely to achieve career success $\left(^{5}\right)$. Again, both managers had these traits; however, Dey was more relentless and he wouldn't rest or eat food until the desired results were obtained.

\section{Core Self-evaluation}

Core self-evaluation is a broad, integrative trait indicated by self-esteem, locus of control, generalized selfefficacy, and (low) neuroticism (high emotional stability) (Judge, 2009). Propositions were drawn from seven diverse literatures (philosophy, clinical psychology research, clinical psychology practice, job satisfaction research, child development theory, personality theory, and social psychology) to introduce the concept of 'core evaluations' (Bono, and Judge, 2003). Judge et al. (1997) suggests that core evaluations are fundamental, bottom-line evaluations that individuals hold about themselves, the world, and others. According to Judge et al., core evaluations influence people's appraisal about themselves, the world and others, and do so subconsciously. People thus differ in the degree to which they like or dislike themselves and whether they see themselves as capable and effective. This selfperspective is the concept of core self-evaluation. Teddy Forstmann, Chairman of the sports marketing giant, IMG, said to himself, "I know God has given me an unusual brain. I can't deny that I have a God-given talent for seeing potential (Sandomir, 2007, c.10, c.14). The McKinsey Quarterly, maintains, "You can win the war for talent, but you must first elevate talent to a burning corporate priority. Then to attract and retain the people you need, you must create and perpetually refine an employee's value proposition - senior management's answer to why a smart, energetic, ambitious individual would want to come and work with you rather than with the team next door. With that done, you must turn your attention to how you are going to recruit great talent and finally develop, develop, develop!" (Chambers et al, 2007). Bhagavan Sri Sathya Sai Baba says, Talent is God. Both managers were hard core on the self-evaluation criteria. They had high esteem about themselves as capable managers.

\section{Self-Monitoring}

An individual has the ability to adjust the behavior to external, situational factors $\left({ }^{6}\right)$. Such individuals show considerable adaptability in adjusting the behavior to external situational factors. Available evidence indicates that self-monitors tend to pay closer attention to the behavior of others and are capable of conforming to the reality (Snyder, 1987). They receive better performance ratings and also emerge as leaders (Day et al., 2002). Both the managers scored very high on these traits.

\section{Risk Taking}

People differ in their willingness to take chances; they differ in the way they resolve decisions involving risk and uncertainty (Blais and Weber, 2006). Popular interpretation of risk attitude, is considered to be a personality trait (Weber, 1998). The propensity to assume or avoid risk has been shown to have an impact on how long it takes managers to make a decision and how much information they require before making a choice. High risk-taking managers made more rapid decisions and used less information in making their choices than did the low risk-taking 
managers. Interestingly, decision accuracy was the same for both groups (Taylor and Dunnette, 1974). Although previous studies have shown managers in large organizations to be more averse to risk than growth-oriented entrepreneurs who actively manage small businesses, recent findings suggest that managers in large organizations may actually be more willing to take risks than entrepreneurs (Jannis and Mann, 1977; Stewart, Jr. and Roth, 2001; Miner and Raju, 2004; and Stewart, Jr. and Roth, 2004). For the work population as a whole, there are also differences in risk propensity (Kogan and Wallach, 1967). Again, Ray was quick at individual decisions and Dey was good where organizations/departments had to make decisions: Dey would confidentially say, 'no paper remains on my table, no decisions are pending.'

\section{High-flyers}

The changing and dynamic work environment and growing opportunities have resulted in an ambitious workforce with multifarious dimensions (Spreitzer et al., 1997, pp. 6-29):

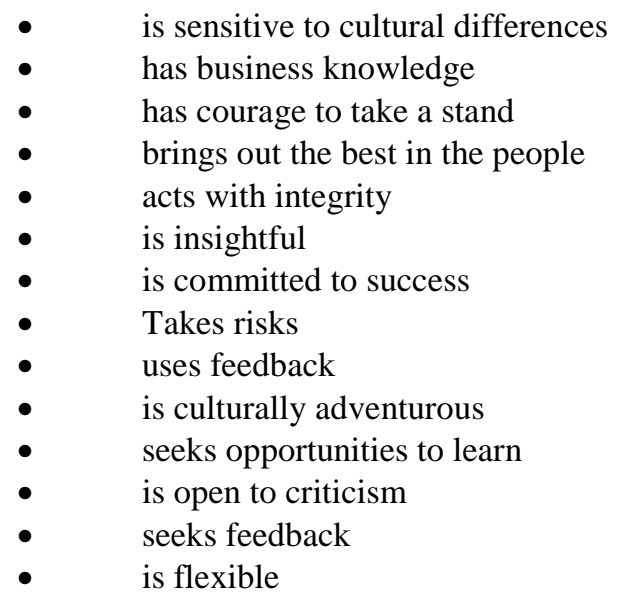

Undoubtedly, Ray wanted to become the CEO, maybe by adopting a 'very fast track.' Dey was content in heading the Geology department.

\section{Integrity, Loyalty and Whistle-blowing}

In organizational life, both integrity and loyalty are given high focus in business operations without much reflection. Integrity is basing an action on sound judgment and seeking unity of wholeness of thought and action. The development of integrity is based upon ethical judgment and a sense of responsibility, as well as the development of appropriate virtues (Winstanley and Woodall, 2000). "Integrity is an interactive event," says Srivastava and Associates (1988) in Executive Integrity. Dialogue (communication) is the operative soul of the human system with integrity. Being clear about organizational values and morals is easy at the level of principles but harder the closer you get to having to operate by them ... People need a forum for private discussion of integrity dilemmas in their work ... the absence of such a forum is the cause of moral stress felt by people in organizations. Managers have to create ... these forums ... Management Professor, James Waters (in Srivastava and Associates 1998), calls them "Good Conversation"... ethical positions can emerge through straight forward exchange and healthy debate wherein leaders take responsibility for their conception of ideas and their success. A pertinent situation is being reported by Badaracco and Ellsworth (1989): James Burke, CEO at Johnson \& Johnson, became concerned a few years ago that managers were treating the company credo with tokenism. He called a special meeting of twenty top managers. "Here's the credo," he began. "If we're not going to live by it, let's tear it off the wall." It wasn't comfortable, but it led to a spirited discussion of company values and the individual managers' own personal values. Burke felt so good about the conversation that he continued to meet with groups of managers all over the world to similarly challenge and repeatedly reinforce the credo. The question remains "how many CEOs would like to emulate that CEO and how many managers have the spirit to get into that level of spirited discussion and take a stand? " 
In contrast to integrity, loyalty is unthinking faithfulness to a person, group, or purpose. If a loyal person were to reflect on his or her action, he or she would have to question whether he or she is loyal to the right thing. Loyalty can range between a high commitment, analogous to a marriage (or a living relationship) and a low level, which requires only the performance of actions contractually agreed upon. In a situation where high loyalty is demanded, but there is no opportunity for developmental openness (which would allow an individual their own values and ethical reasoning), unquestioning conformity is expected of members - one must suppress individuality, ignore one's arguments and perspectives, and accept what one has to do (Smell, 1993).

Some interesting verbatim narrations (concerning loyalty) of the interviews:

CEO:

If I call my senior management team in the afternoon and tell them, 'It is night now.'

Senior Managers:

Most of them would concur and say, 'Yes Sir, it is night now.'

CEO:

'Nobody will have the guts to oppose me.' It means they don't have a voice of dissent a la Boiled-frog effect $\left[^{7}\right]$.

This is analogous to barbaric regimes when the dictators issue an ordinance: 'To bend.' And the response is: 'people start crawling.' It needs an innocent lad to announce, 'but the emperor is naked' (the naked emperor syndrome).

People in organizations may experience conflicts of loyalties. There may be situations concerning whistle blowing ('an attempt by a member or former member of an organization to disclose wrongdoing in or by the organization') (DeGeorge, 1999), in which case they have to choose between being loyal to the organization, to a professional body, to society at large, or to themselves and their families. Less obviously, conflicts may also emerge within the sphere of integrity (Watson, 1998). In the course of performing a job, an employee may discover that a corporation is doing something that the employee believes is injurious to society, and the employees with a sense of moral responsibility who find that their company is injuring society in some way, will normally feel an obligation to get the company to stop its harmful activities and consequentially will often bring the matter to the attention of their superiors (Velasquez, 2009, p.377). Cynthia Cooper of WorldCom, Coleen Bowley of the FBI, and Sherron Watkins of Enron, are the whistleblowers who spilled the beans deliberated by TIME magazine. At times when employees with such responsibility want to share the information and the internal management is refusing to budge-in, and the employee has the temerity to take the matter to the authorities, the management, in extreme cases, can see that the employee is black-balled by other companies in the industry $\left[^{8}\right]$. Many times the employees would not get the requisite legal protection; the only recourse open to them is whistleblowing $\left[{ }^{9}\right]$.

Both Ray and Dey were managers with a high level of integrity and were also seen positively loyal to their employer/s. There was no need of whistleblowing since they could effectively communicate all their concerns to the management.

\section{Organizational Commitment}

Organizational commitment has attracted considerable attention in theory and research because of its attempt to understand the intensity and stability of employee dedication to work organizations (Eisenberger et al., 1990). Organizational commitment has been defined as "bringing-in various aspects". Bateman and Strasser (1984) have provided an operational definition to commitment: "multi-dimensional in nature, involving an employee's loyalty, willingness to exert effort on behalf of the organization, degree of goal and value congruency with the organization, and the desire to maintain membership" (p. 95). According to Buchanan (1974), most scholars define commitment as being a bond between an individual (the employee) and the organization (the employer) through his own definition of commitment. 
A number of studies have evidenced a relationship between organizational commitment and attitudes and behaviors in the workplace (Porter et al., 1974; and Koch \& Steers, 1978). A variety of such antecedents and outcomes of commitments have been identified in the past thirty years (Angle \& Perry, 1981; Mowday et al., 1979; and Hall, 1977). HRD in Organizations should contribute to higher organizational commitment (lles et al., 1990). Both the organizations have showered commitment on their respective managers.

\section{Storytelling}

Stories can be a powerful tool for advocacy, persuasion and leadership; "Tell me the facts and I'll learn. Tell me the truth and I'll believe. But tell me a story and it will live in my heart forever." The leaders of companies need to act as editors - shaping the stories told by employees and customers - to align with the shared vision. Storytelling is one of the most important skills of leadership - you need to be able to craft a compelling story.... (Aaker, 2010). Many organizations have stories about the founders and other significant role holders/visionaries of those organizations. These stories are often told and retold to others with emphasis to drive home positive aspects about the organization and its founder and other significant role holders. Such stories act as a kind of cultural code. In corporate contexts, they help employees to make sense of their workplace and their reasons for working (O'Reilley, 1989). Stories are derived from shared norms, values, and belief systems. Again transmitting values is a challenge for conventional management approaches since values communicated as abstractions are typically "dead on arrival." The key to the effective use of narrative in communicating values lies in narratives that reveal how the conflicts of values get resolved. Models for these stories can be found in parables of the Bible and the same narrative can be used in the corporate context (Denning, 2005).

They are stories about the heroic deeds of the founder - his vision, his dreams, his men (of those days), his networking, his love for the workmen, his sacrifices, his cost-cutting techniques... (Name any positive and often it will be tagged to the founder). It is those MEMORIES that keep the organization ticking.

Deal and Kennedy (1982) refer to this shared perspective as "the way we do things around here." The analysis of stories has gained increased credibility among researchers of organizational culture (Martin, 1982; Schein, 1985; Wilkins, 1978; and Wilkins and Martin, 1979).

The ontological perspective of reality as a social construction permits researchers to study the behavioral and cultural forces that shape an organization's sense of 'meaning.' This view of science comes from the emic tradition - the analysis of subject expression that is typically found in ethnographic research (Pike, 1967). Stories are thus defined as socially constructed accounts of past events that encode culture and are therefore important to members of an organization (Feldman, 1990).

Stories are seldom factual. Instead, they reflect what people believe should be true. For example, contradiction and exaggeration in employees' accounts of the way a founder's stroke provoked organizational discord and chaos were uncovered by Feldman (1990). The "coloring" of actual events reflected a deeper belief that emphasized the founder's role and responsibility for company problems and his corresponding control of his direct reports.

The underlying themes of stories are revealing when we consider what we unconsciously choose to remember and tell (Schrank, 1990).The objective of narrating the stories could be: (1) sparking action (springboard stories); (2) communicating who you are; (3) transmitting values; (4) communicating who the firm is branding; (5) fostering collaboration; (6) taming the grapevine; (7) sharing knowledge; and (8) leading people into the future (Denning, 2005). Both managers (Ray and Dey) believed the rationale behind the stories and told and retold them to others; they also held onto the values because of the stories!

\section{CONCLUSION}

Life is a series of experiences. Knowledge and Judgment come from experience, experience in fact comes from 'good' or 'bad' judgments regarding life situations (Nardia, 2007). Experiences have their basis on one's actions; actions which are for the welfare of the society/ community at large are construed as value based. Even in organizations one can live a value-based life like Ray and Dey. 
Man specializes in various subjects not for the welfare of the world but for his own (emphasis added) self interest. If (man) wants ... peace, he must undertake sacred action (Baba, 2001).

\section{AUTHOR INFORMATION}

Narayan Krishna Prabhu is currently HR Adviser to Sri Sathya Sai Central Trust [SSSCT], India. The paper was submitted by him when he was Dean Academics and Institute Director of Global Institute for Management Science, Kingdom of Bahrain heading their Academics, Research and Consulting Divisions for over 2 years. Prior to this assignment Dr. Prabhu had been associated with several universities, organizations of repute and has held positions in Academics, Industry and Government for the last 35 years. He holds qualifications in management, science, commerce and law. Again, widely travelled, he has presented research papers and training workshops in several countries. His writing focuses on human values along with concomitant societal implications. E-mail: prabhunarayan7@gmail.com

\section{NOTES}

[1]. Boomers (Baby Boomers) are a large cohort born after World War II when veterans returned to their families and times were good. Boomers entered the workforce from the mid-1960s through the mid-1980s. This cohort was influenced by the civil rights movement, the women's movement, the Beatles, the Vietnam War, and baby boom competition. They brought with them distrust for those in authority, at the same time placing emphasis on achievement and material success. They are hard workers and surely want to enjoy the fruits of their labor. They are pragmatists who believe that ends can justify means. Boomers see the organizations that employ them merely as vehicles for their careers [orientation]. Terminal values, such as a sense of accomplishment and social recognition, rank high for them.

[2]. Xers (Generation Xers) have been shaped by globalization, two-career parents ["Double Income Plus Kids" $\rightarrow$ DIPK], MTV, AIDS, and Computers. They value flexibility, life options, and the achievement of job satisfaction. Family and relationships are very important to this cohort. Unlike Veterans (or Traditionalists), Xers are skeptical of those in authority. They are team-oriented and would like increased leisure time and expanded lifestyle options. They rate high true friendship, happiness, and pleasure.

[3]. Veterans (Traditionalists) grew up influenced by the Great Depression, World War II, the Andrew Sisters, and the Berlin Blockade. They believed in hard work, status quo, and authority figures. Once hired, Veterans tended to be loyal to their employer and respectful of authority, hardworking, and practical. Tom Brokaw wrote about them in his book The Greatest Generation. In terms of terminal values, these employees place a great importance on $\boldsymbol{a}$ comfortable life and family security.

[4]. See, for instance, R. C. Becherer and J. G. Maurer, "The Proactive Personality Disposition and Entrepreneurial Behavior Among Small Company Presidents," Journal of Small Business Management, January 1999, pp. 28-36.

[5]. See, for instance, S. E. Seibert, J. M. Crant, and M. L. Kraimer, "Proactive Personality and Career Success," Journal of Applied Psychology, June 1999, pp. 416-427; Seibert, Kraimer, and Crant, "What Do Proactive People Do?" p. 850; and J. D. KammeyerMueller, and C. R. Wanberg, "Unwrapping the Organizational Entry Process: Disentangling Multiple Antecedents and Their Pathways to Adjustment," Journal of Applied Psychology 88, no. 5 (2003), pp. 779-794.

[6]. See M. Synder, Public Appearances/Private Realities: The psychology of self-monitoring [New York: W.H. Freeman, 1987]; and S. W. Gangestad and M. Snyder, Self-Monitoring Appraisal and Reappraisal," Psychological Bulletin, July 2000, pp. 530-555.

[7]. Boiled Frog Effect $\rightarrow$ A frog dropped into boiling water will jump right out; a frog put in cold water, which is slowly brought to boil, will not jump out, cooking to death instead. We have no idea which animal non-lover did this first. 
[8]. For example, see Alan F. Westin, Whistle Blowing, Loyalty and Dissent in the Corporation (New York: McGraw Hill Book Company, 1981); and Frederick Elliston, John Keenan, Paula Lockhart, and Jane van Schaick, Whistleblowing, Managing Dissent in the Workplace (New York: Praeger Publishers, Inc., 1985).

[9]. For example, Ralph Nader, Peter J. Petkas, and Kate Blackwell, Whistle Blowing (New York: Crossman Publishers, 1972); and Charles Peters and Taylors Branch, Blowing the Whistle: Dissent in the Public Interest (New York: Praeger Publishers, Inc., 1972). For a recent comprehensive study of Whistleblowing, see Frederick Elliston, John Keenan, Pasula Lockhart, and Jane van Schaick, Whistleblowing Research, Methodological and Moral Issues (New York: Praeger Publishers, Inc., 1985).

\section{REFERENCES}

1. Aaker, Jennifer. (2010). How to Tell A Story, Stanford Graduate School of Business, Fall 2010.

2. Academy of Management Review (October 1988). Forms of value systems: A Focus on Organizational Effectiveness and Cultural Change and Maintenance.

3. Allport, G. W. (1961). Pattern and Growth of Personality, New York: Holt, Rinehart \& Wineston.

4. Angle, H. L., \& Perry, J. L. (1981). "An empirical assessment of organizational commitment and organizational effectiveness," Administrative Science Quarterly, 26, pp. 1-13.

5. Baba, Bhagawan Sri Sathya Sai. (2001). Human Birth Is To Experience Atmic Bliss, A Discourse given During the International Conference of Bal Vikas Gurus at Prasanthi Nilayam, India on $4^{\text {th }}$ July 2001. Sri Sathya Sai Speaks, Retrieved November 24, 2001, /sssspeaks/volume34/sss34-12.pdf, pp. 165 - 178.

6. Badaracco, J. L. \& Ellsworth, R. R. (1989). "Leadership and the quest for integrity," Boston: Harvard Business School Press.

7. Bateman, T. S. and Crant, J. M. (1993). "The proactive component of Organizational Behavior: A Measure and Corelates." Journal of Organizational Behavior, March 1993, 14(2), pp. 103-118.

8. Bateman, T. S. and Strasser, S. (1984). "A longitudinal analysis of antecedents of organizational commitment." Academy of Management Journal, 21, pp. 95-112.

9. Blais, Anne-Renée., and Weber, Elke. U. (2006). "A Domain-Specific Risk-Taking (DOSPERT) scale for adult populations," Judgment and Decision Making 1 (1), July 2006, pp. 33-47.

10. Bono, Joyce. E., and Judge, Timothy, A. (2003). "Core Self-Evaluations: A Review of the Trait and its Role in Job Satisfaction and Job Performance.” European Journal of Personality, 17: S5-S18 (2003). Published online in Wiley InterScience (www.interscience.wiley.com). DOI: 10.1002/per.481

11. Buchanan, B. II. (1974). "Building Organizational Commitment: The socialization of Managers in Work organizations." Administrative Science Quarterly 1974, 19, pp. 533-546.

12. Chambers, Elizabeth. G., Foulon, Mark., Handfield-Jones, Helen. Hankin, Steven. M., and Michaels III, Edward. G. (2007). The War for Talent, The McKinsey Quarterly: The Online Journal of McKinsey \& Co. Can be also accessed at http://www.mckinseyquarterly.com/article_print.aspx?L2=18\&L3=31\&ar=305. 29/8/2007. [last accessed on $2^{\text {nd }}$ March 2011].

13. Crant, J. M. (2000). "Proactive Behavior in Organizations," Journal of Management, 26 (3), pp. 435-462.

14. Crant, J. M. and Bateman, T. S. (2000). "Charismatic Leadership Viewed from Above: The Impact of Proactive Personality," Journal of Organizational Behavior, February 2000, pp. 63-75.

15. Day, D.V., Shleicher, D. J., Unckless, A.L., Hiller, N. J. (2002). "Self-Monitoring Personality at Work: A Meta-analytic Investigation of Construct Validity," Journal of Applied Psychology, April 2002, pp. 390401.

16. Deal, T. E. \& Kennedy, A. A. (1982). Corporate culture: The rites and rituals of corporate life. Reading, MA: Addison-Wesley.

17. DeGeorge, D. T. (1999). Business Ethics, $5^{\text {th }}$ Edition, (NJ: Prentice Hall).

18. Denning, Stephen. (2005). Mastering the discipline of business narrative, A Leader's Guide to Storeytelling, Mastering the Art \& Discipline of Business Narrative (San Francisco: Jossey-Bass, 2005).

19. Enron's Annual Report 1998.

20. Eisenberger, R., Fasolo, P., Davis-LaMastro, V. (1990). "Perceived organizational support and employee diligence, commitment, and innovation," Journal of Applied Psychology, 75 (1), pp. 51-59.

21. Feldman, S. P. (1990). "Stories as cultural creativity: On the relation between symbolism and politics in organizational change," Human relations 43, pp. 809-419. 
22. Finegan, J. E. (2000). "The impact of personal and organizational values on organizational commitment," Journal of Applied Psychology, 75(1), pp. 51-9.

23. Friedman, M. and Roseman, R. H. (1974). Type A Behavior and Your Heart (New York: Alfred A. Knop).

24. Fry, L. W. (2005). Towards a theory of ethical \& spiritual well-being \& corporate social responsibility through Spiritual Leadership in R. A. Giacolone, C. Dunn, \& C. L. Jurkiewicz's (Eds.). Positive Psychology in business ethics and corporate responsibility.

25. Garg, P. K., and Parikh, I. J. (1988). "Managers and Corporate Cultures: The Case of Indian Organizations," Management International Review 38 (3), pp. 257-275.

26. Haley, G. T. \& Haley, U. C. V. (1998). "Boxing with shadows: competing effectively with overseas Chinese and overseas Indian business networks in the Asian arena," Journal of Organizational Change Management 11 (4), pp. 301-302.

27. Hall, D. (1977). "Organizational Identification as a function of career pattern and organizational type," Administrative Science Quarterly, 17, pp. 340-350.

28. Hatch, M. J. (1993). "The dynamics of organizational culture," Academy of Management Review, 18 (4) pp. 657-693.

29. Hellriegel, Don, Jr., John, Slocum, W. W., \& Woodman, Richard. (2001). Organizational Behavior, Ninth Edition, Singapore, South-Western Thomson Learning.

30. Jannis, I. J., and Mann, L. (1977). Decision Making: A Psychological Analysis of Conflict, Choice, and Commitment. (New York: The Free Press, 1977).

31. Judge, T. A. (2009). "Core Self-Evaluations and Work Success: Association for Psychological Science," Current Directions in Psychological Science 18 (1), pp. 58-62.

32. Judge, T. A., Locke, E. A., \& Durham, C. C. (1997). "The dispositional causes of job satisfaction: A core evaluations approach.” Research in Organizational Behavior, 19, pp. 151-118.

33. Koch, J., \& Steers, R. (1978). "Job attachment, satisfaction, and turnover among public sector employees," Journal of Vocational Behavior, 12, pp. 119-128.

34. Kogan, N., \& Wallach, M. A. (1967). "Group Risk Taking as a Function of Member's Anxiety and Defensiveness,” Journal of Personality, March 1967, pp. 50-63.

35. Lles, P. A., Mabey, C., and Robertson, L. (1990). "HRM practices and employee commitment, possibilities, pitfall and paradoxes," British Journal of Management, 1, pp. 147-57.

36. Martin, J. (1982). Stories and scripts in organizational settings. In A. H. Hastorf and A. M. Isen (eds.), Cognitive social psychology, (pp. 235-305). New York. Elsevier.

37. McShane, Steven L., \& Glinow, Von, Ann, Mary. (2005). Organizational Behavior: Emerging the workplace Revolution, $3^{\text {rd }}$ Edition, New Delhi: Tata McGraw-Hill Edition.

38. Miner, J. B. and Raju, N. S. (2004). "Risk Propensity Differences Between Managers and Entrepreneurs and Between Low- and High-Growth Entrepreneurs: A Reply in a more Conservative Vein. ” Journal of Applied Psychology 89, no. 1 (2004), pp 3-13.

39. Mirabile, R. J. (1996). "Translating company values into performance outcomes," Human Resource Professional, 9 (4), pp. 25-28.

40. Mowday, R., Steers, R., \& Porter, L. W. (1979). "The measurement of Organizational commitment," Journal of Vocational Behavior, 14, pp. 224-247.

41. Nardia, Avi. (2007). Knowledge and Judgment. Retrieved November 24, 2011, www.usadojo.com/pdffiles/knowledge-and-judgment.pdf

42. Neal, C. (1999). "A conscious change in workplace," Journal for Quality \& Participation, 22(2), pp. 27-30.

43. O'Reilley, C.(1989). "Corporations, culture, and commitment: Motivation and social control in organizations.” California Management Review, 28, pp. 438-453.

44. Parikh, I. J., and Garg, P. K. (1990). Indian Organizations: Value Dilemmas in Managerial Roles, in A. M. Jarger and R. N.Kanungo (eds.), Management in Developing Countries, Routledge: London.

45. Pike, K. (1967). Language in relation to a unified theory of the structure of behavior. The Hague, The Netherlands: Morton.

46. Porter, L. W., Steers, R. M., Mowday, R. T., \& Boulian, P. (1974). “Organizational commitment, job satisfaction, and turnover among psychiatric technicians," Journal of Applied Psychology, 59, pp. 603-609.

47. Rao, N. P. (2004). Human Values: Development, Excellence \& Fulfillment, Sri Prasanthi Publications. Trust, Hyderabad, India. 
48. Robbins, Stephen P., Judge, Timothy A., Sanghi, Seema. (2009). Organization Behavior: Personality and Values, $13^{\text {th }}$ Edition, Pearson Education, Inc, India.

49. Rokeach, M. (1973). The Nature of Human Values, The Free Press, New York: NY.

50. Sagie, A \& Elizur, D. (1996). "Work Values: A Theoretical Overview and a Model of Their Effects," Journal of Organizational Behavior, pp. 503-14.

51. $\quad$ Sandomir, R. (2007). "Star Struck," New York Times, January 12, 2007, pp. c.10, c.14.

52. Sanghi, Seema. (2002). "Ethical Issues at Work: A Comparative Study between UK and Indian Managers." Vikalpa: The Journal of Decision Makers, 27, January-March, 2002.

53. Schien, E. H. (1985). Organizational Culture and Leadership: A Dynamic View, Jossey_Bass, San Francisco, CA.

54. Schrank, R. (1990). Tell me a story: a new look at real and artificial memory. New York: Macmillan.

55. Schwartz, S. (1999). "A Theory of Cultural Values and Social Implications for work," Applied Psychology: An International Review 48, pp. 23-47.

56. Seibert, S. E., Kraimer, M. L., and Crant, J. M. (2001). "What Do Proactive People Do? A Longitudinal Model Linking Proactive Personality and Career Success," Personnel Psychology, Winter 2001.

57. Sinha, J. B. P. (1995). The cultural context of Leadership and Power, Sage, International, New Delhi.

58. Smell, R. S. (1993). Developing Skills for Ethical Management. (London: Chapman and Hall).

59. Snyder, M. (1987). Public Appearances/ Private Realities: The psychology of self-monitoring, New York: W.H. Freeman.

60. Spreitzer, G., McCall, W., and Mahoney, J. (1977). "Early Identification of International Executive Potential," Journal of Applied Psychology 82, pp .6-29.

61. Stewart, W. H. Jr. and Roth, L. (2001). "Risk propensity Differences between Entrepreneurs and Managers: A Meta-analytic Review.” Journal of Applied Psychology, February, 2001, pp. 145-153.

62. Stewart, W. H. Jr. and Roth, L. (2004). "Data Quality Affects Meta-anaytic Conclusions: A Response to Miner and Raju (2004) Concerning Entrepreneurial Risk Propensity," Journal of Applied Psychology 89 (1), pp.14-21.

63. Stoner, James, A. F., Freeman, Edward, R. \& Gilbert, R. Jr., Daniel. (2002). Management, Prentice Hall of India Private limited, Sixth edition.

64. Taylor, R. N., and Dunnette, M. D. (1974). "Influence of Dogmatism, Risk-Taking, Propensity, and Intelligence on Decision-Making Strategies for a Sample Industrial Managers," Journal of Applied Psychology, August 1974, pp. 420-423.

65. Tett, Robert. P., and Burnett, Dawn. D. (2003). A Personality Trait-Based Interactionist Model of Job Performance. American Psychological Association, Inc. 0021-9010/03 DOI: 10.1037/0021-9010.88.3.500. Journal of Applied Psychology 200388 (3) 500-517.

66. Tripathi, R. C. (1990). "Interplay of Values in the Functioning of Indian Organizations," International Journal of Psychology, 25, pp. 715-734.

67. Velasquez, Manuel. G. (2009). Business Ethics: Concepts \& Cases, Sixth Edition. Pearson Education, Inc.

68. Watson, T. J. (1998). "Ethical codes and Moral Communities: The Gunlaw Temptation, the Simon Solution and the David Dilemma," in M. Parker (ed.), Ethics \& Organization (London: Sage).

69. Weber, E. U. (1998). Who's afraid of a little risk? New evidence of general risk aversion. In Shanteau, B. A. Mellers, \& D. Schum (eds.), Decision Research from Bayesian Approaches to Normative Systems: Reflections on the Contributions of Ward Edwards, pp.53-64, Norwell, MA: Kluwer.

70. Weihrich, Heinz \& Koontz, Harold. (1994). Management: A Global Perspective, McGraw-Hill International edition, Tenth Edition, Singapore.

71. Wilkins, A. L. (1978). Organizational stories as an expression of management philosophy. Unpublished doctoral thesis, Business School, Stanford University, Palo Alto, CA.

72. Wilkins, A. L. \& Martin, J. (1979). Organizational Legends (Stanford University research paper no. 521). Palo Alto, CA: Stanford University.

73. William, R. M. Jr. (1979)."Change and Stability in Value Systems: a sociological perspective," in Rokeach. M. (ed.) Understanding Human values, the Free Press, New York; NY, pp. 15-46.

74. Winstanley, D. and Woodall, J. (eds.) (2000).Ethical Issues in Contemporary Human Resource Management (London: Macmillan). 